Tersedia online di: http://ejournal-balitbang.kkp.go.id/index.php/JP
e-mail:jurnalpari@gmail.com
JURNAL PARI
Volume 4 Nomor 2 Desember 2018
p-ISSN: 2502-0730
e-ISSN : 2549-0133

\title{
RESISTENSI IMPLEMENTASI IBLIMS PADA PERPUSTAKAAN LINGKUP BADAN RISET DAN SUMBER DAYA MANUSIA KELAUTAN DAN PERIKANAN (BRSDMKP)
}

\author{
Nanung S. Rijal \\ Politeknik Kelautan dan Perikanan Bitung \\ Diterima tanggal : 21 September 2018 Diterima setelah perbaikan : 21 November 2018 \\ disetujui terbit : 18 Desember 2018
}

\begin{abstract}
ABSTRAK
Dalam era informasi dewasa ini perpustakaan telah mengalami transformasi mengikuti era digital. Kondisi ini tak terkecuali merubah peran dan fungsi perputakaan dalam menyediakan dan menyampaikan informasi yang dimiliki kepada pemustakanya. Secara berangsur-angsur telah terjadi polarisasi serta perubahan dari perpustakaan tradisional menuju perpustakaan modern. Peluang dan tantangan inilah yang mengharuskan perubahan pola pikir (mindset) dalam pengelolaan perpustakaan. Tulisan ini dimaksud untuk memberikan gambaran resistensi dan solusinya terkait implementasi IBLiMS di perpustakaan lingkup BRSDMKP. Metode penelitian yang digunakan adalah kualitatif, dengan teknik pengumpulan data menggunakan metode wawancara, dan observasi. Hasil dari penelitian ini, diharapkan pustakawan dan organisasi perpustakaan dapat memanfaatkan setiap tantangan dan peluang dengan cara-cara efektif dan inovatif agar tetap survive dalam kondisi lingkungan yang terus berubah.
\end{abstract}

Kata kunci : Perpustakaan Digital; Revolusi Industri 4.0; Pustakawan; Resistensi; IBLiMS.

\begin{abstract}
In the information era like today, the library has undergone an eradigital transformation. This condition is no exception to changing the role and functions of circulation in providing and conveying information that is owned to its customers. Polarization and change from traditional libraries to modern libraries have been gradual. These opportunities and challenges require changes in mindset in library management. This article is intended to provide an overview of the resistance and solution related to IBLiMS implementation in the BRSDMKP scope library. The research method used is qualitative, with data collection techniques using interview methods, and observations. The results of this study are expected that librarians and libraries can take advantage of every challenge and opportunity in effective and innovative ways to survive in changing environmental conditions.
\end{abstract}

Keywords: Digital Library; Industrial Revolution 4.0; Librarian; Resistance; IBLiMS. 


\section{PENDAHULUAN}

Kemajuan teknologi informasi yang semakin pesat telah membawa pengaruh terhadap lembaga penyedia informasi publik. Perpustakaan adalah salah satu dari lembaga-lembaga pengelola informasi, terutama informasi yang bermuatan ilmu pengetahuan. Pemanfaatan teknologi informasi telah menciptakan ledakan informasi yang melibatkan seluruh infrastruktur informasi. Pada sisi lain, tuntutan pengguna informasi sudah berubah. Pengguna informasi saat ini membutuhkan layanan yang cepat, tepat dan nyaman. Oleh sebab itu kemampuan perpustakaan dalam hal ini pustakawan mengikuti perkembangan yang ada adalah suatu hal yang mutlak.

Trend teknologi internet yang semakin gencar dan perkembangan sumber daya informasi baru yang begitu cepat, serta kemajuan sistem akses dalam temu kembali informasi akan menyeret dunia perpustakaan dan informasi untuk mengemas koleksi perpustakaan dari tradisional ke arah digitalisasi koleksi. Dengan demikian mengakibatkan pengolahan sumber informasi di perpustakaan pun akan ikut berubah. Sumber informasi yang semestinya dikumpulkan, diolah, disebarkan dan dilestarikan tidak lagi hanya dalam bentuk media cetak maupun rekam namun juga harus dapat diakses melalui media terpasang (baik online atau offline). Kondisi tersebut akan membawa dampak terhadap perpustakaan secara keseluruhan, dimana perpustakaan akan mengalami transisi menuju suatu ekosistem digital. Berbagai isu yang berkaitan fenomena di atas akan menarik untuk di bicarakan termasuk penyiapan sumber daya manusia yang ada guna menangani pelayanan perpustakaan digital.

Dalam beberapa tahun terakhir, semenjak meletusnya revolusi sunyi (silent revolution) dekade silam yang perlahan, tapi mengancam keberadaan media cetak. Kini berbagai informasi paper-based, yang selama ini merupakan primadona, sekarang telah banyak yang tersedia dalam bentuk digital. Bahkan sebagian produk informasi yang dihasilkan ada yang hanya tersedia dalam bentuk digital. Perkembangbiakan sumber daya informasi digital sebagai salah satu alternatif yang semakin penting dalam pemenuhan kebutuhan menuju masyarakat informasi.

Pertumbuhan pesat di teknologi informasi khususnya berbasis digital telah melahirkan istilah "digital library". Perpustakaan digital adalah suatu lingkungan perpustakaan dimana berbagai obyek informasi (koleksi, images, suara dan video klip) disimpan dan diakses dalam format digital semakin meningkat baik judul baru maupun lama termasuk koleksi grey literatur yang sebelumnya sulit diperoleh. Berkaitan dengan kecenderungan tersebut perpustakaan dalam hal ini pustakawan dituntut untuk bersikap responsif dan inovatif terhadap perubahan yang terjadi dalam memenuhi kebutuhan harapan pemustakanya. Hal ini penting jika perpustakaan ingin survive dalam lingkungan yang terus berubah. Maka tidak heran di perpustakaan dan lembaga informasi pada umumnya, anggaran habis untuk melakukan persiapan teknologi informasi perpustakaan misalnya pembelian hardware, software dan pelatihan staf. Namun satu yang sering luput oleh pimpinan dalam suatu organisasi atau lembaga adalah akan selalu ada resistensi, penolakan terhadap suatu kebijakan karena staf bukanlah robot yang akan berjalan lurus sesuai komando pimpinan apalagi kepentingannya tidak terakomodir dengan baik dalam kebijakan yang baru tersebut baik kebijakan lembaga tersebut ataupun lembaga induk.

\section{TINJAUAN PUSTAKA}

\section{a. Revolusi Industri 4.0}

Sejarah revolusi industri dimulai dari industri 1.0, 2.0, 3.0, hingga industri 4.0. Fase industri merupakan real change dari perubahan yang ada. Industri 1.0 ditandai dengan mekanisasi produksi untuk menunjang efektifitas dan efisiensi aktivitas manusia, industri 2.0 dicirikan oleh produksi massal dan standarisasi mutu, industri 3.0 ditandai dengan penyesuaian massal dan fleksibilitas manufaktur berbasis automasi dan robot. Industri 4.0 selanjutnya hadir menggantikan industri 3.0 yang ditandai dengan cyber fisik dan kolaborasi manufaktur (Hermann et al, 2015; Irianto, 2017). Istilah industri 4.0 berasal dari sebuah proyek yang diprakarsai oleh pemerintah Jerman untuk mempromosikan komputerisasi manufaktur.

Lee et al (2013) menjelaskan, industri 4.0 ditandai dengan peningkatan digitalisasi manufaktur yang didorong oleh empat faktor: 1) peningkatan volume data, kekuatan komputasi, dan konektivitas; 2) munculnya analisis, kemampuan, dan kecerdasan bisnis; 3) terjadinya bentuk interaksi baru antara manusia dengan mesin; dan 4) perbaikan instruksi transfer digital ke dunia fisik, seperti robotika dan 3D printing. Liffler dan Tschiener (2013) menambahkan, prinsip dasar industri 4.0 adalah penggabungan mesin, alur kerja, dan sistem, dengan menerapkan jaringan cerdas di sepanjang rantai dan proses produksi untuk mengendalikan satu sama lain secara mandiri. 
Hermann et al (2016) menambahkan, ada empat desain prinsip industri 4.0. Pertama, interkoneksi (sambungan) yaitu kemampuan mesin, perangkat, sensor, dan orang untuk terhubung dan berkomunikasi satu sama lain melalui Internet of Things (IoT) atau Internet of People (IoP). Prinsip ini membutuhkan kolaborasi, keamanan, dan standar. Kedua, transparansi informasi merupakan kemampuan sistem informasi untuk menciptakan salinan virtual dunia fisik dengan memperkaya model digital dengan data sensor termasuk analisis data dan penyediaan informasi. Ketiga, bantuan teknis yang meliputi; (a) kemampuan sistem bantuan untuk mendukung manusia dengan menggabungkan dan mengevaluasi informasi secara sadar untuk membuat keputusan yang tepat dan memecahkan masalah mendesak dalam waktu singkat; (b) kemampuan sistem untuk mendukung manusia dengan melakukan berbagai tugas yang tidak menyenangkan, terlalu melelahkan, atau tidak aman; (c) meliputi bantuan visual dan fisik. Keempat, keputusan terdesentralisasi yang merupakan kemampuan sistem fisik maya untuk membuat keputusan sendiri dan menjalankan tugas seefektif mungkin. Secara sederhana, prinsip industri 4.0 menurut (Hermann et al dalam Yahya, 2018) dapat digambarkan sebagai berikut.

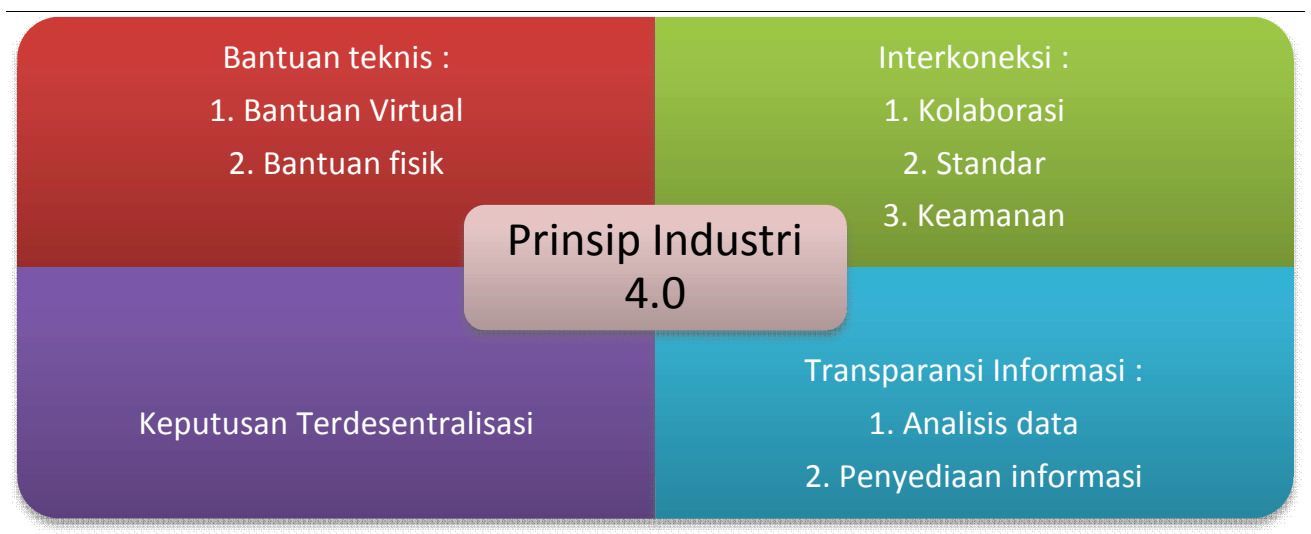

Gambar 1. Prinsip Industri 4.0

Perkembangan revolusi industri mampu mengubah pekerjaan dan organisasi. Organisasi informasi terutama perpustakaan berkembang kearah perubahan frontal dengan mengadopsi teknologi dalam cara berorganisasi. Pengaruh ini menjadikan suatu organisasi tersebut semakin bergerak cepat agar tidak tertinggal sehingga munculnya persaingan baru yang tidak dapat dihindarkan. Perubahan arah tersebut membuat pesaing bisa muncul dari mana saja atau organisasi di seberang lautan kota lain. Persaingan yang tajam ini membuat organisasiorganisasi yang sudah mapan perlu untuk mempertahankan diri. Suatu organisasi yang sukses adalah organisasi yang mampu mempertahankan diri dari persaingan-persaingan tersebut.

Trend sosial media sebagai "pilar kelima", yang melengkapi tiga pilar demokrasi "trias politica" plus pers sebagai "pilar keempat" merubah total bentuk medianya, dari yang bertemu fisik berubah ke bentuk lain bertemu menjadi dunia maya. Bahkan seakanakan bertemu fisik di tunjang oleh teknologi video conference. Dari berbagai banyak pendukung di atas, lantas apakah perubahan suatu organisasi informasi tersebut suatu kebetulan atau memang sudah terencana. Penulis fokus pada perubahan terencana karena organisasi harus mempertimbangkan konsep
Planning sebagai bentuk penataan organisasi yang lebih baik. Dimana ada 2 (dua) tujuan dari perubahan yang terencana yaitu :

1) Perubahan yang terencana berusahan meningkatkan kemampuan organisasi tersebut dalam menyesuaikan diri dengan perubahan yang terjadi di lingkungannya

2) Perubahan terencana dimaksudkan untuk mengubah perilaku karyawan

Organisasi informasi dalam hal ini perpustakaan jika ingin bertahan hidup dan masih menjadi tempat favorit bagi pemustakanya, harus menjadikan segala perubahan menjadi perubahan yang terencana. Karena ketika teknologi informasi merambah ke Indonesia, lembaga informasi beradaptasi terhadap perkembangan teknologi komputer dan internet dan mentransformasikan teknologi tersebut dalam kegiatan sehari-hari mereka, karena komunikasi antara perpustakaan dengan pemustakanya terbuka luas melalui sosial media.

\section{b. Resistensi terhadap Perubahan}

Resistensi terhadap perubahan merupakan bentuk aksi reaksi dari perubahan situasi. Resistensi lebih merupakan ekspresi dari adanya pendapat atau 
pemikiran yang tidak merasa cocok dengan hal yang baru akibat munculnya perubahan. Berikut ini adalah definisi mengenai resistensi terhadap perubahan dari berbagai literatur, antara lain :

Penelitian resistensi Oreg dalam Heny T.W Dyah (2015) menyatakan konsep resistensi sebagai karakteristik individu yang mencerminkan pendekatan umum (negatif) ke arah perubahan dan kecenderungan untuk menghindari atau melawannya. Lebih lanjut lagi bahwa sumber resistensi berasal dari diri individu yang meliputi keengganan untuk kehilangan kontrol, kekakuan kognitif, kurangnya ketahanan psikologis, intoleransi untuk periode penyesuaian terlibat dalam perubahan, preferensi untuk tingkat rendah stimulasi dan hal baru, serta keengganan untuk menyerah pada kebiasaan lama.

Lawanda (2015 : 189) meminjam istilah Behavior which intended to protect an individual from the effects or real or imaged change (Alvin Zandler; Soeharso 2006). Zandler memposisikan individu dalam posisi untuk menjaga dirinya dari akibat perubahan. Jadi individu tersebut merasa terancam bila terjadi perubahan sehingga ia melakukan perilaku resistensi.

Any conduct that serve to maintain the status quo in the face of pressure to alter the status quo (Zaltman \& Duncan dalam Suharso, 2006) menurut Zaltman, resistensi individu itu untuk memelihara status quo. Individu akan senantiasa ingin berada dalam zona nyaman atau berusaha memelihara comfort zone-nya

Dari 3 (tiga) konteks definisi tersebut menunjukkan resistensi terhadap perubahan sebagai suatu kumpulan percakapan mengenai substansi, makna dan penyebab kesuksesan dan keberhasilan masa lalu daripada suatu respon terhadap kondisi aktual dan situasi yang melingkupi usulan perubahan itu sendiri. Resistensi terhadap perubahan tidak hanya berkaitan dengan apa yang terjadi saat ini, tetapi juga mencakup apa yang telah terjadi dan pemaknaan akan kemungkinan di masa depan.

Resistensi adalah suatu reaksi dan respon yang secara alamiah timbul pada setiap perubahan yang terjadi pada individu atau organisasi. Resistensi terjadi ketika mereka yang melakukan perubahan belum menemukan upaya yang tepat untuk mencapai titik keseimbangan baru agar perubahan menjadi efektif. Dalam lingkup organisasi, resistensi terhadap perubahan dapat berasal dari 3 (tiga) sumber yaitu :

1) Technical Resistance yaitu berasal dari kebiasaan mengikuti prosedur umum dan berlandaskan pemikiran akan biaya yang diinvestasikan untuk kondisi status quo

2) Political Resistance dapat muncul bila perubahan organisasi mengancam stakeholder seperti top eksekutif. Biasanya perubahan organisasi berimplikasi pada perbedaan alokasi seperti modal, anggaran pelatihan dan karyawankaryawan yang bertalenta

3) Cultural Resistance merupakan bentuk dari sistem dan prosedur yang memperkuat status quo, serta mempromosikan suatu konformitas dari nilai-nilai, norma dan asumsi yang telah ada dengan mempertanyakan bagaimana hal ini dapat di implementasikan.

\section{c. Perubahan Mindsite}

Kecenderungan menuju perpustakaan modern, maju, elektronis merupakan ciri yang ditujukan terhadap perilaku masyarakat dalam pengelolaan informasi. Hal tersebut sebagaimana disampaikan oleh Stueart dan Morgan dalam Rachmad Himawan (2006) berikut ini :

\section{Perubahan Mindsite (Stuart dan Morgan, 2002)}

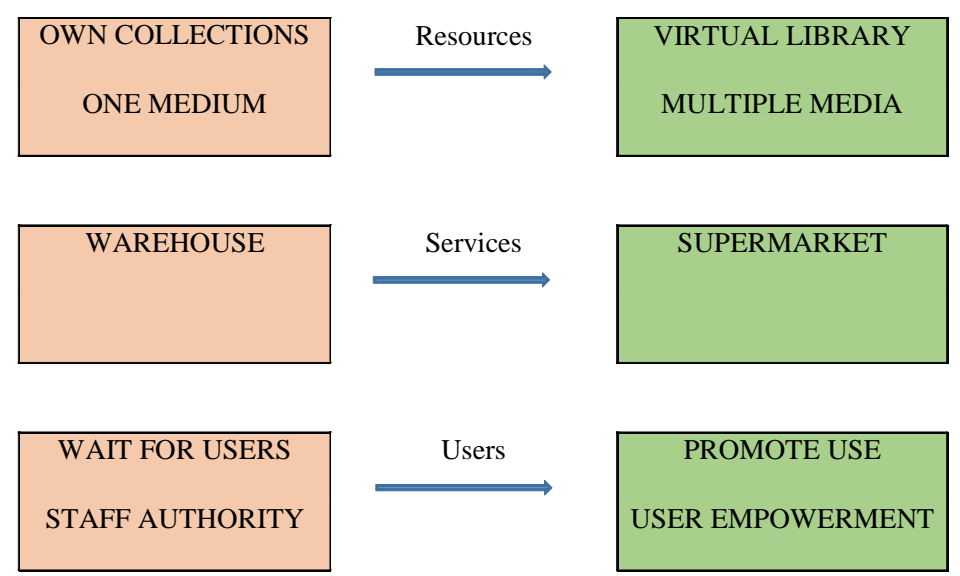

Gambar 2. Information Paradigm Shift 
Secara berangsur-angsur telah terjadi polarisasi serta perubahan dari perpustakaan tradisional menuju perpustakaan modern. Kondisi inilah yang mengharuskan perubahan pola pikir (mindset) dalam pengelolaan perpustakaan. Dalam konsep perubahan pola pikir (mindset) yang dikemukakan oleh Stuert dan Morgan dapat dijelaskan bahwa (1) dari segi sumber daya perpustakaan bahwa koleksi perpustakaan terdiri satu media (own collections) dan berubah sekarang kedalam koleksi virtual atau digital (virtual library), (2) dari segi jasa layanan perpustakaan semula dalam gudang sekarang berubah pada pelayanan supermarket, (3) dari segi pemustaka maka perpustakaan yang dulu hanya menunggu (wait for users) maka sekarang perpustakaan dipromosikan kepada pengguna (promote use users).

\section{METODOLOGI}

Metode yang digunakan dalam penelitian ini adalah metode kualitatif. Menurut Denzim dan Lincoln dalam Moleong (2014:5) menyatakan bahwa penelitian kualitatif adalah penelitian yang menggunakan latar alamiah, dengan maksud menafsirkan fenomena yang terjadi dan dilakukan dengan jalan melibatkan berbagai metode yang ada. Teknik pengumpulan data dengan menggunakan metode wawancara, studi literatur dan observasi.

\section{PEMBAHASAN}

Dalam rangka pengembangan perpustakaan di lingkup Badan Riset dan Sumber Daya Manusia Kelautan dan Perikanan (BRSDMKP) serta layanan kepada pemustaka yang sebaik-baiknya, perpustakaan perlu dikelola secara profesional menurut sistem baku dan ketentuan umum yang berlaku berdasarkan UU No. 43 tahun 2007 dan PP No. 24 tahun 2014. Tentang pelaksanaan UU No. 43 tahun 2007 khususnya dalam peningkatan mutu layanan, perpustakaan perlu meningkatkan kerjasama dan mutu layanan dengan memanfaatkan sistem jejaring perpustakaan yang berbasis teknologi informasi. Oleh karenanya perpustakaan BRSDMKP berupaya menyatukan layanan katalog induk bersama (union catalog) perpustakaan melalui web server Integrated BPSDMKP Library Management System (IBLiMS).

Agar kerjasama dapat berjalan dengan baik perpustakaan lingkup BRSDMKP melaksanakan sosialisasi dan pelatihan kepada UPT lewat pengembangan automasi Senayan Library Management System (SLiMS). Upaya ini dimaksudkan sebagai pengembangan layanan perpustakaan melalui upload data ke katalog induk Bersama (union cata- log) Integrated BPSDMKP Library Management System (IBLiMS). Melalui IBLiMS kerjasama dalam pengembangan automasi dan kerjasama layanan perpustakaan dapat di tingkatkan.

Kedudukan perpustakaan lingkup BRSDMKP adalah sebagai bagian dari unit kerja pelayanan teknis tepatnya di bawah koordinasi seksi dokumentasi dan publikasi yang berjumlah 43 UPT dan tersebar di seluruh Indonesia. Perpustakaan lingkup BRSDMKP memegang peranan penting dalam pengelolaan dan pusat informasi dan penelitian bidang kelautan dan perikanan. Faktanya di lapangan terjadi resistensi terhadap kebijakan tersebut. Masing-masing unit pelaksana teknis mempunyai staf perpustakaan dan perpustakaan yang kondisinya berbeda. Ada yang hanya mempunyai 1 (satu) orang staf perpustakaan dan ada yang lebih dari 3 (tiga) orang staf perpustakaan. Staf perpustakaan ada yang sudah mempunyai jabatan fungsional pustakawan dan ada yang belum. Begitu juga status Pendidikan ada yang berlatar belakang pendidikan ilmu perpustakaan dan ada yang non ilmu perpustakaan. Terakhir jenjang pendidikan ada yang magister, sarjana, dan diploma bahkan ada yang hanya lulusan SLTA.

Keadaan dan fasilitas perpustakaan juga dari setiap unit pelaksana teknis juga tidak jauh berbeda. Beberapa unit ada yang memiliki fasilitas ruangan (gedung) ada yang sudah dilengkapi dengan sarana ruang baca, koleksi, rak, meja-kursi, dan komputer namun juga masih ada beberapa jauh dari standar nasional perpustakaan yang telah ditetapkan. Dari uraiain diatas, terlihat bahwa perpustakaan lingkup BRSDMKP keadaannya tidak sama baik dari segi sumberdaya pengelola, gedung, sarana dan prasarana lainnya.

Nampaknya memang ada resistensi terhadap kebijakan tersebut yang dengan sengaja tidak ingin masuk kedalam perubahan. Sehubungan faktor manusia, terdapat 2 (dua) kelompok yang di bagi berdasarkan sikap pustakawan terhadap implementasi terhadap sistem IBLiMS yaitu :

1) Positif dan cenderung menerima

Kelompok pertama adalah pustakawan dan pengelola perpustakaan yang menerima sistem automasi dan union catalog ini secara antusias dan memperlihatkan minat dengan mempelajari sistem dan terlibat dalam program-program pendidikan dan pelatihan.

2) Negatif dan cenderung menolak meskipun enggan mengakuinya

Kelompok kedua adalah pustakawan dan pengelola perpustakaan yang menolak sistem automasi dan union catalog, biasanya pustakawan 
dan pengelola perpustakaan yang lebih senior. Anggota kelompok kedua ini tidak mempercayai "benda tak di kenal" tersebut dan berusaha menghindari benda itu. Persepsinya membuat anggota kelompok kedua itu terbelenggu oleh perasaan khawatir dan lebih tertarik pada sistem konvensional.

Sikap kelompok yang menolak kebijakan sistem tersebut barangkali dapat dipahami, karena bagaimanapun penerapan sistem automasi dan katalog induk bersama akan menyebabkan perubahan pada sistem dan prosedur kerja pada perpustakaan tersebut. Tentunya tidak semua orang diuntungkan oleh perubahan tersebut, terutama orang-orang yang merasa kurang mampu menggunakan komputer akan merasa cemas karena berpeluang digantikan oleh yang lebih bisa mengoperasikan komputer. Demikian juga, berapa kebiasaan dalam bekerja tentunya perlu berubah dan tidak semua orang dapat mengubah kebiasaannya.

Melibatkan pustakawan dalam pembangunan sistem tersebut sejak awal dapat menjadi salah satu cara mengubah sikap negatif pustakawan yang menolak sistem automasi dan katalog induk bersama ini. Pustakawan bisa diyakinkan mengetahui hal-hal yang dibutuhkan dalam ekosistem IBLiMS ini, sehingga dapat menyiapkan dirinya agar tetap terlibat di dalam sistem tersebut.

Perubahan dari sistem manual menjadi sistem terkomputerisasi juga perlu dilakukan bertahap. Pustakawan yang biasanya membuat konsep katalog, secara berangsur-angsur diminta dan dilatih untuk memindahkan data bibliografis di layar komputer nantinya. Perubahan secara bertahap tentunya tidak akan membuat shock dan tanpa disadari telah bekerja otomatis ke dalam "automasi" dan "katalog induk bersama". Pada gilirannya sistem komputerisasi dalam perpustakaan dapat dilakukan sebagai pengganti pena dan kertas dengan cara dan prosedur kerja yang tidak berubah.

Walaupun peran untuk mengatasi resistensi diatas powernya dirasa kurang kuat, tetapi ini malah menjadi tantangan tersendiri bagi penulis untuk memberikan masukan terkait serangkaian strategi guna mengatasi persoalan diatas, meskipun diakui itu membutuhkan waktu. Ada 5 (lima) strategi yang perlu di pertimbangkan dan dicoba dalam mengatasi resistensi implementasi IBLiMS di perpustakaan lingkup BRSDMKP, antara lain :

a. Analisa Kebutuhan (Need Analysis)

Dalam tahap awal ini pertanyaan yang muncul adalah apakah otomasi dan katalog induk bersama
IBLiMS memang di perlukan. Untuk menjawab itu tidak dapat dijawab hanya berdasarkan perkiraan semata tetapi harus diadakan studi untuk menentukan kebutuhan apa yang diperlukan sesuai tujuan yang didasarkan pada visi dan misi perpustakaan sesuai lembaga induknya dalam hal ini tujuan peningkatan mutu layanan dan perpustakaan lingkup BRSDMKP.

b. Studi Kelayakan (Feasibility Study)

Apabila penentuan kebutuhan dan tujuan bersama sudah dilakukan, maka tahap berikutnya adalah melaksanakan studi kelayakan. Tahapan disini meliputi penilaian komponen sebagai berikut : (1) technically feasibility, apakah secara teknis kondisi perpustakaan lingkup BRSDMKP layak untuk implementasi IBLiMS ini. Apakah saranaprasarana pendukung yang ada sesuai standar untuk mendukung program tersebut. (2) economically profitable, apakah secara anggaran untuk kelengkapan standar perpustakaan ini mencukupi dan menguntungkan sesuai visi dan misi perpustakaan dan lembaga induknya. (3) socially acceptable, secara sosial apakah SDM perpustakaan dapat menerima.

\section{c. Pemilihan Software}

Pemilihan software hanya di perlukan apabila ingin membangun database perpustakaan digital (sebagai penyedia informasi), kriteria pemilihan untuk mengembangkan program IBLiMS antara lain meliputi : (1) access point, apakah program tersebut dapat ditelusur melalui judul, pengarang dan subjek atau kombinasi kesemuanya. (2) user friendly, bahwa program yang ada mudah digunakan, tidak membutuhkan pelatihan yang lama, pustakawan dan pemustaka dapat berinteraksi dengan mudah dan cepat. (3) sustainability, dalam membangun perpustakaan digital untuk program jangka panjang. Dimana agar investasi yang ditanamkan tidak sia-sia seperti update developer dan komunitas yang ada. (4) corporate identity, agar program yang ada agar bisa sama maka perlu ada modifikasi khusus dalam pengembangan IBLiMS lewat Slims sehingga konsep, bentuk dan prosedur kerja antar UPT perpustakaan sama. Dengan begitu pustakawan dan pemustaka lingkup BRSDMKP dalam melaksanakan kegiatan rutin perpustakaan tidak mengalami kendala berarti.

\section{d. Pelaksanaan}

Dalam tahap ini, khususnya untuk pembangunan IBLiMS harus mempunyai prioritas. Dimana prioritas ini tergantung pada masing-masing perpustakaan. Untuk memulai pembangunan 
katalog induk bersama ini perlu pembentukan dan pelatihan mempersiapkan database local content bersama seperti hasil penelitian, hasil pengabdian masyarakat, skripsi, tesis, disertasi dan jurnal ilmiah yang diterbitkan oleh lembaga induk atau sekitar.

e. Evaluasi

Seperti pada program dan kegiatan perpustakaan lainnya, evaluasi untuk implementasi IBLiMS pada perpustakaan lingkup BRSDMKP harus dilakukan secara terus menerus dalam satu periode tertentu. Seharusnya standar pertemuan pustakawan dan pengelola perpustakaan lingkup BRSDMKP 2 (dua) kali dalam setahun namun jika dirasa berat minimal sekurang-kurangnya 1 (satu) kali dalam setahun. Pertemuan ini untuk mengetahui apakah perkembangan program yang telah dicanangkan apakah sudah tercapai dan memuaskan pemustaka. Tingkat kepuasan pemustaka dan target capaian kinerja pustakawan harus kita monitor dan hasil dari monitoring tersebut dapat digunakan sebagai dasar untuk mengambil keputusan apakah program IBLiMS ini perlu di lanjutkan, disempurnakan atau malah digantikan.

Dari kelima strategi diatas, tahapan tersebut sebenarnya merupakan suatu cara untuk mampu mengurangi dan menghilangkan resistensi yang ada. Namun fakta dilapangan masing-masing unit ketika menjadi aktor tunggal, maka tidak akan bisa melakukan banyak hal.

Mengutip The Clayston Christensen Reader dalam Rhenald Kasali (2017) dari kondisi diatas, perubahan pengembangan perpustakaan yang ada di KKP dalam hal ini lingkup BRSDMKP kondisinya sebagai berikut:

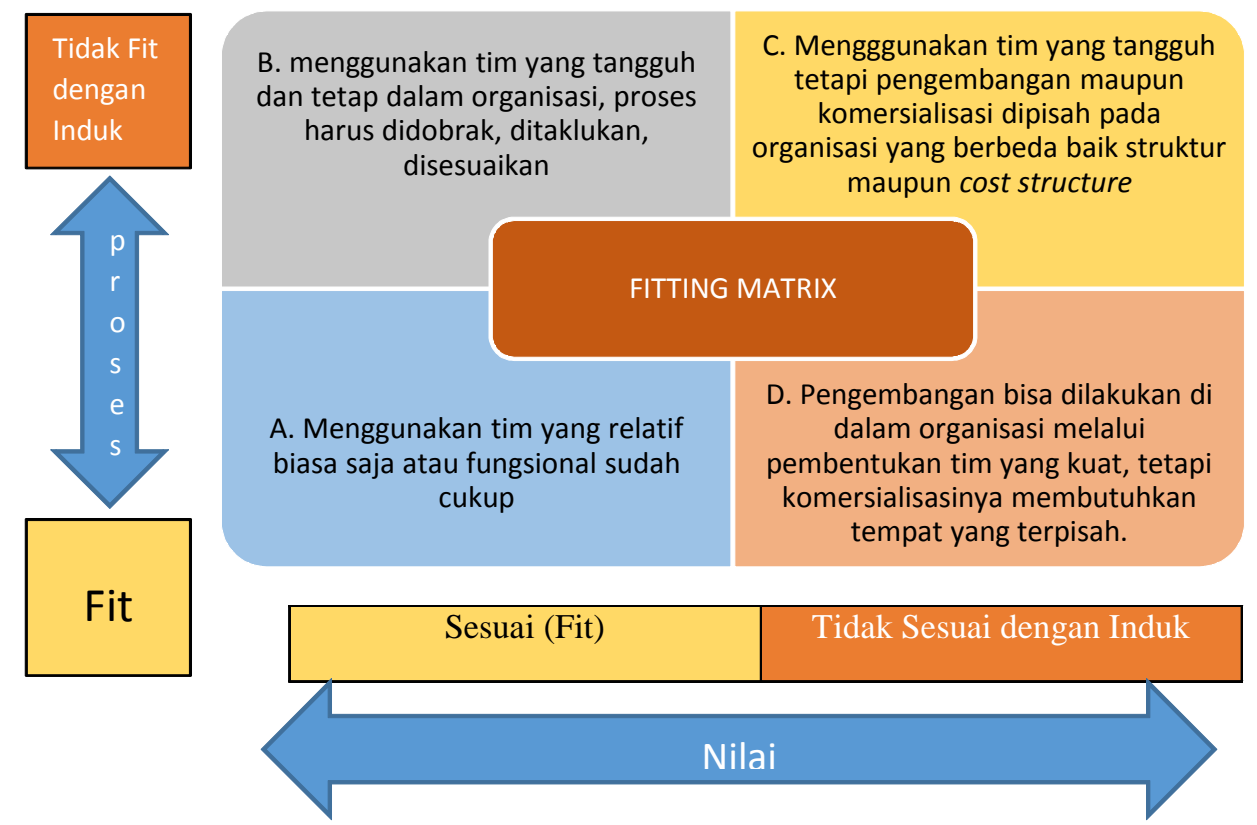

Wilayah A. Inisiasi yang baru sudah sesuai dengan kemampuan dan nilai-nilai perusahaan sehingga tidak dibutuhkan tambahan tim di luar perusahaan.

Wilayah B. Proyek yang ada cocok dengan nilainilai perusahaan tetapi tidak dengan prosesnya. Dengan demikian, dibutuhkan pembentukan tim khusus yang terdiri dari manusia-manusia yang tangguh dengan cara koordinasi dan interaksi yang mungkin juga baru.

Wilayah C. Kondisi ini terjadi ketika perusahaan menghadapi kondisi yang sangat mendisrupsi perusahaan sehingga tidak bisa lagi diimbangi dengan proses dan nilai-nilai perusahaan saat ini.
Wilayah D. Masih di wilayah C, tetapi ternyata prosesnya dianggap mampu dilaksanakan perusahaan, meskipun nilainya bertentangan. Organisasi tersebut berfungsi khusus untuk mengomersialkan hasil inisiatif.

Dari matriks diatas, pada kasus IBLiMS permasalahan yang ada adalah lembaga induk sering kali menganggap ada satu strategi yang bisa digunakan untuk semua kondisi. Padahal kondisi unit perpustakaan lingkup BRSDMKP masuk kategori wilayah B dimana "nilai" organisasi fit sesuai dengan lembaga induk namun "proses" didalamnya yang tidak fit. Maka dari itu lembaga induk perlu berani mendobrak sistem dan membangun tim baru yang tangguh dengan mengambil sumberdaya pustakawan 
dan pengelola perpustakaan dari unit yang ada yang disesuaikan dari dalam organisasi. Dengan cara mengumpulkan pustakawan dan tenaga pengelola perpustakaan yang berbasis creative thinking, sosial media communication, internet of things, big data, fintech dan community development yang baik di tingkat lokal dan nasional untuk membangun ekosistem digital perpustakaan Kementerian Kelautan dan Perikanan yang hasilnya di bagi ke unitunit yang lain.

\section{KESIMPULAN}

Dalam proses implementasi IBLiMS pada perpustakaan lingkup Badan Riset dan Sumber Daya Manusia Kelautan dan Perikanan (BRSDMKP) memerlukan strategi khusus untuk mengurangi resistensi yang ada. Diketahui bahwa strategi diatas dapat terlaksana dengan baik jika mendapat dukungan manajerial dan teknis yang kuat. Dimana ternyata aktor dalam penyelesaian resistensi, tidak hanya satu tapi bisa lebih banyak lagi. Di harapkan pimpinan dan lembaga induk mengajak semua unit untuk bahumembahu sesuai tupoksinya masing-masing mengambil bagian dari langkah-langkah diatas.

Untuk menghadapi hal tersebut bila perlu pustakawan dan organisasi perpustakaan harus direstrukturisasi sebagai jawaban atas visi dan peran baru sesuai tantangan dan peluang yang timbul dari revolusi industri 4.0. Tantangan dan peluang ini untuk menentukan kembali posisi pustakawan, tenaga pengelola perpustkaan dan perpustakaan itu sendiri dalam mencari cara-cara efektif dan inovatif guna memenuhi harapan pemustaka. Hal ini penting jika perpustakaan ingin terus tumbuh dan berkembang, bahkan survive dalam lingkungan yang terus berubah.

\section{DAFTAR PUSTAKA}

Ardoni. 2017. Teknologi Informasi dan Perpustakaan. Jakarta: Sagung Seto.

Diah, Heny T.W. 2015. Resistensi Perubahan Disponsional dan Pengaruhnya Terhadap Kinerja Operator Sistem Akuntansi Instansi BKKBN. Jurnal Ekonomi dan Bisnis. 26 (3): 223.

Hartono. 2017. Manajemen Sistem Informasi Perpustakaan : Konsep, Teori dan Implementasi. Yogyakarta: Gava Media.

Hartono. 2016. Dasar-dasar Organisasi Informasi : Panduan Pengatalogan Perpustakaan Berbasis $M A R C$. Jakarta: Sagung Seto.

Lawanda, Ike Iswary. 2015. Integrasi Pustakawan Menuju Masyarakat Informasi : Suatu Perspektif Sosial-Budaya. Jakarta: Sagung Seto

Moleong, L. 2014. Metodologi Penelitian Kualitatif. Bandung: Remaja Rosdakarya.

Nugraha, Pepih. 2012. Citizen Journalism. Jakarta: Penerbit Buku Kompas.

Rimbarawa, Kosam dkk. 2013. Peran IPI Dalam Meningkatkan Kompetensi Pustakawan Menuju Sertifikasi. Jakarta: Sagung Seto

Yahya, Muhammad. (2018, Maret). Era Industri 4.0 : Tantangan dan Peluang Perkembangan Pendidikan Kejuruan Indonesia. Makalah Disampaikan pada Sidang Terbuka Luar Biasa Senat, di Universitas Negeri Makasar. 